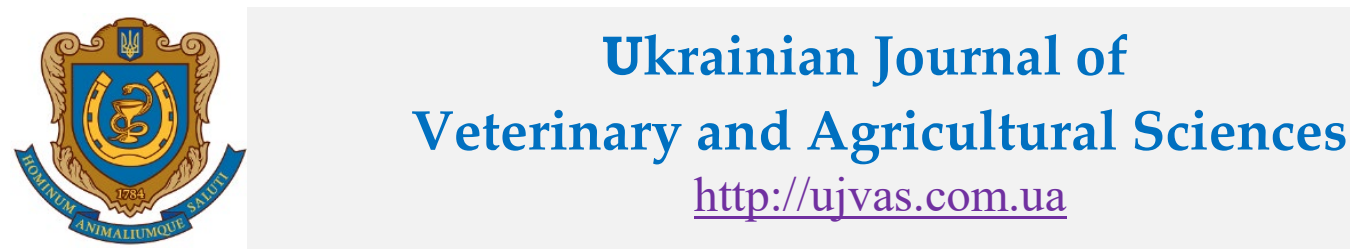

Stepan Gzhytskyi National University of Veterinary Medicine and Biotechnologies Lviv

\begin{tabular}{l|l|l} 
original article & UDC 619: 616.99:636.293 $\quad$ doi: 10.32718/ujvas2-3.10
\end{tabular}

Volume 2

Number 3

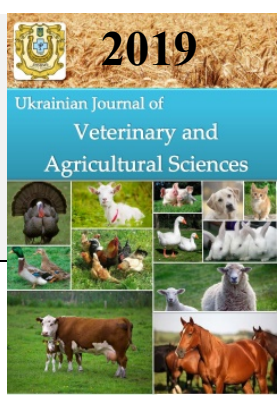

\title{
Environmental and sanitary and hygienic aspects of the prevention of wild helminthosis in the contemporary climate change
}

\author{
V. O. Pepko ${ }^{1}$, S. V. Zhigalyuk², R. M. Sachuk ${ }^{2}$ \\ ${ }^{1}$ Rivne State Humanities University, Plastova Str., 29a, Rivne, 33028, Ukraine \\ ${ }^{2}$ Research Epizootology Station IVM NAAS, Knyazya Volodymyra Str., 18, Rivne, 33028, Ukraine
}

\begin{tabular}{|c|}
\hline $\begin{array}{l}\text { Article info } \\
\text { Received 11.11.2019 } \\
\text { Received in revised form } \\
\quad 12.12 .2019 \\
\text { Accepted } 13.12 .2019\end{array}$ \\
\hline $\begin{array}{l}\text { Correspondence author } \\
\text { Roman Sachuk } \\
\text { Tel.: +38-097-671-90-63 } \\
\text { E-mail: sachuk.08@ukr.net }\end{array}$ \\
\hline $\begin{array}{l}2019 \text { Pepko V. O. et al. This is an } \\
\text { open-access article distributed under } \\
\text { the terms of the Creative Commons } \\
\text { Attribution License, which permits } \\
\text { unrestricted use, distribution, and } \\
\text { reproduction in any medium, } \\
\text { provided the original author and } \\
\text { source are credited. }\end{array}$ \\
\hline$(\mathrm{cc}) \mathrm{Br}$ \\
\hline 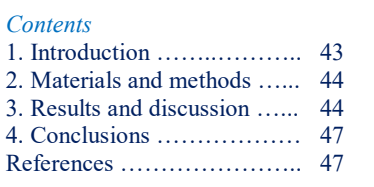 \\
\hline
\end{tabular}

\begin{abstract}
The intensification of the hunting industry leads to an increase in the number of animals and creates conditions for the spread of invasions, incl. helminthic. The transboundary position of the Western regions of Ukraine contributes to the expansion of the species composition and habitats of helminths, which in the current climate change can complicate the epizootic situation of dangerous invasions. On the basis of the literature and the results of our own research, potential risks to the hunting economy for the emergence of new helminthiasis caused by the speciesspecies have been identified. In the work the influence on the helminth fauna of ungulates, kept under conditions in the aviary, modifying and regulating environmental factors, is analyzed. The modern changes in the phenology and ontogeny of pathogens of mass infestations, first of all in geo-helminths, have been investigated. For the causative agent of dictiocaulosis, prolongation of the seasonality of invasion by larvae has been established. It is shown that the decrease in the extent and intensity of invasion of individual trematodes correlates with the dynamics of their intermediate hosts. The data on the effectiveness of remediation with aqueous solutions of polyhexamethyleneguanidine chloride, landing sites were obtained by decontamination of soil in wildlife clusters, in order to minimize their infestation by nematode larvae. The proposed remedy is an organic compound, does not scare away animals, but by contacting organic and inorganic constituents of the soil and lose their potential toxicity. Efficiency of destruction of larvae of Strongylid and Strongylate in the sample ranged from $78 \%$ to $87 \%$, and in the surface (up to $5 \mathrm{~cm}$ ) soil layers - 96-100\%. Research findings should be reflected in planned antiparasitic measures.
\end{abstract}

Key words: ungulates, aviary, helminthosis, invasiveness, regulating and modifying factors, ecology.

\section{Citation:}

Pepko, V. O., Zhigalyuk, S. V., \& Sachuk, R. M. (2019). Environmental and sanitary and hygienic aspects of the prevention of wild helminthosis in the contemporary climate change. Ukrainian Journal of Veterinary and Agricultural Sciences, 2(3), $43-47$.

\section{Introduction}

In the context of increasing anthropogenic load on the environment, the issue of biodiversity conservation, the reproduction of ecosystem components, and the rational use of natural resources are extremely important. One of the ways of preserving and replenishing the faunistic complexes of natural biocenoses, indigenous to the past or introduced species, is the breeding of animals, including hunting, captive and semi-voluntary, carried out for conservation or commercial purposes. Thus, thanks to artificial breeding measures, many species of animals, such as bison and bison, were preserved from complete extinction (Veselyi, 2010; Danilkin, 2011; Ponomar \& Kruchynenko, 2014; Sokolov \& Mykytyn, 2014).

The intensification of the hunting industry leads to an increase in the number of animals and, accordingly, the volume of exploitation of their populations. At the same time, due to biotechnical and hunting-economic measures, such as the regulation of predator numbers, organization of feeding, diet enrichment and protection, the influence of modifying factors, which inhibited the growth of the number of animals, is significantly reduced. On the other hand, the influence of regulatory, biotic factors is increasing. For example, as the number of livestock grows, conditions for the spread of invasions, including helminthiasis, which is a natural factor in the regulation of the number of animals, and also cause significant economic losses due to the reduction of fertility, market and trophy qualities, culling of the products obtained (Govorka et al., 1988; Egorov, 1995; Subbotin, 2011). They also adjust seasonal dynamics, and hence the magnitude and intensity of the invasion, the recent changes in seasonal isotherms, which have already been documented by us and in local natural populations potentially dangerous for the economic activity of helminth species. 
Research of helminth fauna in new economic conditions, study of invasive features, biological features of parasites, their phenology in modern climatic changes, popularization of new scientific data, will help to strengthen the control of epizootic status in agrocenoses, development of scientifically substantiated measures (Davudov, 2008; Dovhii et al., 2011; Subbotin, 2011).

The introduction into practice of modern science and best practices in the prevention of parasitic diseases, the voluntary keeping of wild ungulates, will contribute to the increase of their livestock, increase the production of quality, environmentally friendly, cost-effective production is especially advisable in modern conditions.

The purpose of the study is to analyze, under current climatic changes, the impact on ungulates of ungulates in the aviary, modifying and regulating environmental factors.

\section{Materials and methods}

The research was conducted in hunting farms of the aviary type and in adjacent livestock farms of Rivne and Volyn, located on the territory of Volyn Polissya. A retrospective and prospective analysis of the spread of cattle helminthiasis in the Rivne region was conducted on the basis of their own materials and statistical reporting data from the Rivne Regional State Veterinary Laboratory. Laboratory studies were performed on the basis of the laboratory of parasitology of the Rivne NDVS, and later in the Experimental Station of epizootology of the Institute of Infectious Diseases of NAAS. The results of more than 600 coproscopic studies have been performed using conventional methods. The study of the intensity of molluscan lesions by larval forms of trematodes was performed according to the method of V. I. Zdun (Zdun, 1957), by compressor method, followed by microscopy.

The theoretical analysis of scientific literary sources, synthesis, generalization, comparison, concretization are used in the work.

\section{Results and discussion}

In recent years, in the hunting farms of Ukraine, the number of wild ungulates has declined. Thus, according to the data of the Statistical Bulletin "Doing Hunting", the total number of ungulates in Ukraine in 2012 was 239.6 thousand heads, in 2015 - 231.3 thousand heads, in 2016 - 220.2 thousand heads. The greater interest of hunting area users is to breed wild animals in aviaries, for the purpose of letting them into their own lands and for sale to other farms. Between 2000 and 2016, the state increased the number of wild ungulates from 44 to 220 , and the number of the main stock reached almost 3.000 (Vedennia myslyvskoho hospodarstva u 2014-16 rr). The majority of the stock of captive ungulates belongs to the representatives of the contract of ruminants: deer, fallow deer, mouflon. Due to the deteriorating epizootic of African wild boar plague, work on breeding and keeping these livestock is temporarily suspended.

According to the data of the State Statistics Service of Ukraine in the three surveyed farms of Rivne and Volyn oblasts (BARS LLC, Sokil MSC and DLMG Zverevske), there has also been an increase in livestock since 2016 . by 2018, the number of aviaries increased from 112 to 223 individuals.
Helminthoses of ungulates have a number of features caused by both physical and geographical conditions - the territory is divided between two climatic zones and is rich in natural biotopes of adjacent feeders, and mainly mixed nature of trematodose-nematode infestations complicated by special geochemical and ecological areas.

According to Kharchenko V. A. (Kharchenko, 2004), 161 species of helminth parasites of wild ungulates have been registered in Europe, 99 species have been identified in Ukraine; 56 species of elk are parasitized, noble deer -78 , spotted deer -17 , roe deer -86 , fallow deer -40 , bison -5 , mouflon -64 , boar -35 species of helminths. Species that do not have a narrow specialization in the choice of the owner predominate - parasite in several species of ungulates, including farm animals. Relatively specific are ruminants, including 3 species of deer, 2 of elk and roe deer. Indeed species specification is revealed in 26 species (Kharchenko, 2004).

According to the statistical reports and own half-century studies, in the agricultural and wild animals of the region, 43 species of helminths were identified, 15 of them flat (7 trematodes, 8 - cestodes) and 28 species of nematodes. The identification of 10 helminth species was performed at the level of genus traits. Conducted by us helmintovoscopic studies of wild (aviary) ungulates showed the presence in the European fallow deer of LLC-company "Bars" in Derazhnensky forest of Kostopil district, Rivne region, Strongyloides papillosus (EI - $100 \%$ ), Dictyocaulus viviparus (EI $60 \%$, Eab - $60 \%$ ) EI - $60 \%$ ), Trichostrongylus capricola (EI $-20 \%$ ) found in the aviary at feeding sites. According to Pepko V. A. and co-authors (2016), larvae of the european species (EI - $100 \%$, II - 32), spotted deer (EI - $100 \%$, II - 24) and surveyed flocks were registered in the region. cattle (EI $-70 \%$, II -15$)$. The composition of the helminth fauna depended on the season. In autumn and winter trematodes prevailed, in spring and summer - nematodes. According to our research, the mouflon, which is kept exclusively in the aviaries of Sokil LLC (Kostopil district, Rivne region) in the region, was affected by Dictyocaulus filaria, Trichostrongylus colubiformis, Muellerius capillaries. Terns infected with Liorchis sp., D. viviparus, Trich. colubiformis, M. capillaries, and in the fallow deer $-D$. viviparus, Trich. colubiformis with an extent of $100 \%$ (Pepko et al., 2016). In wild boars, Fasciola hepatica infestation is common. A peculiarity of parasite fauna of open-air farms, where a considerable number of individual species are collected in a limited area, is the partial restriction of contacts with potential sources of invasion. As a consequence, a small variety of helminths is observed, with high rates of invasion magnitude and intensity.

A somewhat different situation in free-living ungulates, which is typical of carrying out unauthorized, unmanaged, migration, including in transboundary territories, carrying accompanying parasites. In view of this, there is a need to expand the range of their potentially hazardous species, taking into account zoogeographical and climatic conditions. Thus, according to A. M. Subbotina, the parasitic system of wild ungulates of Belarus includes 37 species. In particular, bison revealed 16 species of helminths, elk - 17, roe deer 19 , boar -16 species. In the wild ungulates of Belarus, 17 species are found, which are also found in domestic ruminants and carnivores, as well as in pigs (Subbotin, 2011). Given the similar conditions and openness to animals of the boundaries between adjacent, close territories, we should 
pay attention to the search for these species in our country. For example, since 2014, recorded cases of infection of animals Sparganum spirometra erinacei.

Among the parasites we have discovered are dominated by representatives of the Nemathelminthes type, which, by their life cycle features, are predominantly geo-helminths, and thus show a close dependence of phenology on the abiotic environmental factors. Broader connections with environmental conditions are inherent in Plathelminthes flatworms: modifying factors affect both the worm organism and its intermediate hosts, participants in complex developmental cycles.

There are significant climatic changes in the world that may affect the geographical distribution of ungulates. According to the Ukrainian Hydrometeorological Institute, in recent years, the average winter temperature in Polissya has increased by $1.5-1.8^{\circ} \mathrm{C}$, against $0.5-1{ }^{\circ} \mathrm{C}$ in Ukraine. As a result, the average annual temperature increase in the Northwestern region of Ukraine is the largest and exceeds the long-term average by $2-2.5{ }^{\circ} \mathrm{C}$. In addition, the precipitation deficit reaches up to $30 \%$ of the annual amount. Meteorological and eco-geographical characteristics erase or alter the conventional boundaries of physical and geographical zoning: it is noted that the southern boundary of the Mixed Forests zone has moved $50-100 \mathrm{~km}$ to the north. Such modifying factors usually have an impact on invertebrates, including parasites: areas of distribution change, ontogeny accelerates, phenology changes.

In the region, weather changes that have taken place over the last decade reveal trends that are characteristic of the continental climate:

- high and abnormally high air temperatures and short but excessive rainfall in summer;

- low temperatures, heavy rainfall in the first half of winter and relative warming at the end of the season;

- a sharp decrease in air temperature in early spring, which is protracted.

Temperature has a direct and indirect effect on the physiology of helminths, determining the rate of ontogenesis and life expectancy. Active life of poikilothermic animals is possible only within a certain temperature range, which may be different in different species. Experimental data show that with increasing temperature, the duration of development gradually decreases, with a certain range of temperatures reaches a minimum, and with a further increase in temperature may again increase. The dependence of the rate of development on temperature is partly explained by the usual physical and chemical laws. According to the VantGoff-Arrhenius rule, "the rate of the chemical process (metabolism in the body) increases by $10^{\circ}$ by $2-3$ times". The temperature factor, of course, is determining, but not the only one. Equally important is the relative humidity and absolute residence environment. Some features of phenology and ontogeny of dominant helminth species under modern climatic changes are traced in field materials.

The analysis, for the period 1992-2009, of the results of coproscopic studies of samples taken from farm animals showed that the region is dominated by: trematodoses fasciculosis and paramphistomatosis, and nematodoses dictiocaulosis of ruminants. Dynamic increase in the index of invasiveness of animals with fasciolosis was noted. Thus, from 1992 to 1994, the average percentage of infected ruminants was 3.3 and $5.9 \%$, respectively, in 1996, the extensinvation rate of cattle with fascioli was $10.7 \%$, and in 2001
$-11.85 \%$. During the period 1992-2001, the level of fascia invasion in the animals of the northern (Polesie) and southern (Forest-steppe) regions of the region increased dynamically, accounting for 14.3 and $8.4 \%$, respectively, in 2001 . Retrospective indicators of the extent of paramphistomatous invasion are close in value: $5.4 \%$ in 2002, $7.8 \%$ in 2004 (Zhyhaliuk et al., 2009).

In animals from the northern regions, the studied index was always higher than the same as in the animals from the southern regions, but since the mid-90s there has been a gradual approximation of the magnitudes of extensinvasion of the north and south. The high rates of contamination of animals from both physical and geographical zones are explained by the adjacency of the territories and the common water basin, as well as by the high values of the coefficient of faunistic similarity of the fauna of the intermediate feeders. However, high percentages indicate the presence of processes and factors contributing to the development of infestation, among which are the number of biotopes of intermediate trematodes and the extent of their invasion by larval helminth stages. Why, in turn, contribute to the spring excess precipitation and the growth of the June isotherm, typical of the 2000s. The exception was 2019, which was characterized by a lack of precipitation in the north and moderate droughts in the south.

To confirm this, we conducted a study of mollusks collected from biotopes within aviary farms and surrounding settlements. Directly 15 natural terrestrial species (Zebrina cylindrical, Teneba fructosum, Helicella candicans, Helicella sp., Jaminia potaniniana, Helix vulgaris, Helix pomatia, Helix lutescens, Succinea putris, Cochiluscima subgracea, Cochiluscima subgracea, Cochiluscima subgracea, Achaea capresta, Cochilcapa arbepiaxa, Achaea cresta, arabicus subsp. nemoralis, Monacha carthusiana, Chondrulla tridens) and 12 aquatic species (Lymnea truncutula, Lymnea stagnalis, Lymnea auricularia, Galba palustris, Planorbis (Anisus) vortex, Planorbis planorbis, Planorbis (Anisus) lencostoma, Radix ovataent Bithyat, Bithyata, Bithyata, Bithyata, Bithyata corneus, Viviparus contectus) shellfish. Of these, 9 species have been shown to participate in the spread of helminth infestations: Helicella candicans, Helicella sp., Succinea putris, Monacha carthusiana, Chondrulla tridens - intermediate hosts of Dicrocoelium lanceatum; Lymnea truncutula, Lymnea stagnalis, Lymnea auricularia - intermediate hosts of Fasciola hepatica and Fasciola gigantica; Planorbis (Anisus) vortex, Planorbis planorbis, Planorbis (Anisus) lencostoma, Radix ovate are intermediate hosts of the Paramphist of the River Leorchys, and Bithynia leachi, Bithynia tentaculata are intermediate hosts of Opistorhis felineus, Prosthogonimus ovat. Settlement density from 8 to 15 molluscs per square meter, EI from 0.2 to $65 \%$.

Of the 9 permanent biotopes surveyed small ponds found in all. An analysis of the magnitude of invasion of molluscs showed that the most susceptible to infection with the agent of fasciulosis is L. truncutula, which, depending on the season of year, is infested with larvae of fascioles by 3 $40 \%$. So in May - June 2015, the infestation rate reached $3-20 \%$, and since July it increased to $40 \%$, keeping the value until the end of the pasture season - in October. In 2019 , no cases of fasciulosis, either wild boar or cattle, were recorded. A probable cause was the drying up of aquatic biotopes of planorbids, which led to their absence during the grazing season, or reduced the number to 1-4 copies $/ \mathrm{m}^{2}$. 
The abundance of terrestrial molluscs, especially quarantine species of slugs, is considerable and requires further study of their possible epizootic significance.

More pronounced data on the effects of temperature and humidity were obtained for D. filaria, which was isolated from sheep and mouflon in the farms of Kostopil district. In 1993, the following experiment was conducted to study the timing of maturation of the dictiocaulus larvae to the invasive stage and the timing of their viability. In the artificial biotope, at the beginning of each month, 2 packages of group samples of faeces, weighing up to $300 \mathrm{~g}$, were laid, pre-protecting them from drying out. Bookmarks were made in sunlit and shaded areas. Three days later, daily larvoscopy was started, before invasive larvae appeared. Further, the samples were examined 5 days before the death of helminths. For the differentiation of dictiocauluses from other nematodes, staining was standard procedure using meth- ylene blue solution. Under similar conditions, the experiment was repeated in 2019, recording the temperature and humidity.

It has been found that the ontogeny starts at a threshold temperature of $+6{ }^{\circ} \mathrm{C}$, which lasts $4-6$ days in a row. As shown in table 1 , there is a species-specific temperature optimum and an appropriate humidity regime of the surrounding air. In the summer months, the temperature is optimal, deviations in terms of invasive larvae - insignificant, and the duration of existence determines the humidity of the environment: the larvae of stages 2 and 3 sustained dehydration for 20-25 days, then mostly died. In 2019, the determinants of the invasiveness of juvenile diktiokaul, the number of atmospheric opals and the duration of the dry season, became. However, due to the abnormally warm autumn-winter months, the seasonality of the infestation became longer.

Table 1

Terms of maturation and survival of dictiocaulus larvae

\begin{tabular}{|c|c|c|c|c|c|c|c|c|}
\hline \multirow{3}{*}{ Months } & \multicolumn{3}{|c|}{1993 p. } & \multicolumn{5}{|c|}{2019 p. } \\
\hline & \multirow{2}{*}{$\begin{array}{c}\mathrm{T}_{\text {midi }} \\
{ }^{\circ} \mathrm{C}\end{array}$} & \multirow{2}{*}{$\begin{array}{c}\text { Invasive } \\
\text { stage, } \\
\text { days }\end{array}$} & \multirow{2}{*}{$\begin{array}{c}\text { Life } \\
\text { expectancy, } \\
\text { days }\end{array}$} & Light & \multirow{2}{*}{$\begin{array}{c}\text { Invasive } \\
\text { stage, } \\
\text { days }\end{array}$} & \multirow{2}{*}{$\begin{array}{c}\text { Life } \\
\text { expectancy, } \\
\text { days }\end{array}$} & \multirow{2}{*}{$\begin{array}{c}\mathrm{T}_{\text {midi }} \\
{ }^{\circ} \mathrm{C}\end{array}$} & \multirow{2}{*}{$\begin{array}{c}\text { Amount of } \\
\text { precipita } \\
\text { tion, } \mathrm{mm}\end{array}$} \\
\hline & & & & Shadow & & & & \\
\hline \multirow[b]{2}{*}{ January } & \multirow[b]{2}{*}{$-8,9$} & - & - & 棌 & - & - & \multirow[b]{2}{*}{-5} & \multirow[b]{2}{*}{31} \\
\hline & & - & - & 0 & - & - & & \\
\hline \multirow{2}{*}{ February } & \multirow{2}{*}{-6} & - & - & 㴽 & 26 & 4 & \multirow{2}{*}{$+0,9$} & \multirow{2}{*}{14} \\
\hline & & - & - & 0 & - & - & & \\
\hline \multirow{2}{*}{ March } & \multirow{2}{*}{-2} & - & - & 垱 & 18 & 14 & \multirow{2}{*}{$+4,2$} & \multirow{2}{*}{24} \\
\hline & & - & - & 0 & 19 & 28 & & \\
\hline \multirow[b]{2}{*}{ April } & \multirow[b]{2}{*}{$+6,9$} & 18 & 60 & 垱 & 19 & 59 & \multirow[b]{2}{*}{$+9,6$} & \multirow[b]{2}{*}{35} \\
\hline & & - & - & $\Theta$ & 19 & 60 & & \\
\hline \multirow{2}{*}{ May } & \multirow{2}{*}{$+13,6$} & 10 & 21 & 㴽 & 10 & 35 & \multirow{2}{*}{$+14,4$} & \multirow{2}{*}{102} \\
\hline & & 12 & 35 & 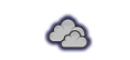 & 10 & 40 & & \\
\hline \multirow{2}{*}{ June } & & 5 & 28 & 㴽 & 4 & 20 & & 10 \\
\hline & $+16,1$ & 7 & 35 & $\theta$ & 6 & 25 & $+21,1$ & 48 \\
\hline & & 7 & 21 & 彩 & 7 & 22 & & \\
\hline July & $+19,8$ & 8 & 35 & 0 & 9 & 41 & $+18,4$ & 84 \\
\hline$\Delta$ & $10=$ & 7 & 50 & 㴽 & 6 & 35 & 106 & 75 \\
\hline August & $+18,5$ & 8 & 57 & 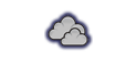 & 6 & 49 & $+19,6$ & 15 \\
\hline Sontombar & 20 & 10 & 55 & 棌 & 9 & 37 & +146 & 10 \\
\hline Septemoer & $+12,9$ & 14 & 65 & $\infty$ & 11 & 45 & $+14,0$ & 40 \\
\hline O & 1 & - & - & 㵛 & 16 & 55 & 7 & 00 \\
\hline OCtoOC & 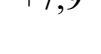 & - & - & $\infty$ & 18 & 65 & $+5,1$ & 9,9 \\
\hline Novembor & 03 & - & - & 㴽 & 27 & 29 & 57 & 0 \\
\hline Novemoer & $-0,3$ & - & - & 0 & 30 & 5 & $+5,1$ & 2,9 \\
\hline Droombor & 21 & - & - & 澊 & - & - & 22 & 2 \\
\hline Decemoer & $-2,1$ & - & - & $\theta$ & - & - & $+2,3$ & 25 \\
\hline
\end{tabular}

During the maintenance of wild ruminants in captivity, their way of life and nutrition changes, and anthropogenic factor (transport of animals, feeding of imported feeds, organization of sanitary control) begins to play a leading role in the formation of the parasitic system (Zdun, 1957). Given the prolongation of the invasive activity of geo-helminths, the rehabilitation of sub-sites, namely the disinfection of soil at wildlife sites, is essential to minimize their re-infestation. To this end, we have proposed the use of aqueous solutions 
of polyhexamethyleneguanidine (PGMG) chloride, at a concentration of $0.4 \%$, at a dose of $200-300 \mathrm{ml} / \mathrm{m}^{2}$.

The basis for the experiment was the results of the study of the effects of PGMG solutions on larvae of intestinal Strongylid and pulmonary Strongylate extracted from faeces. In particular, larvae of Strongyloides (Strongyloides sp.) And Dictyocaulus (Dictyocaulus sp.) PGMGhl in concentrations of $0.1-0.2 \%$ were reduced by $70-80 \%$, with drug concentrations of $0.3 \%$ efficiency reached $90-95 \%$.

Test results in the enclosure of Bars LLC, showed that in the surface layer of soil PGMG solutions effectively neutralize both pathogenic microorganisms and helminth larvae. Efficiency of destruction of larvae of Strongylid and Strongylate in the sample ranged from $78 \%$ to $87 \%$, and in the surface (up to $5 \mathrm{~cm}$ ) soil layers - 96-100\% (Pepko et al., 2016). In addition, PGMG preparations are odorless, do not scare off animals, but lose their potential toxicity by contacting organic and inorganic soil constituents.

The results of the research were taken into account by the farms when planning the treatment and preventive antiparasitic measures of livestock rehabilitation.

\section{Conclusions}

The transboundary position of the Western regions of Ukraine contributes to the expansion of the species composition and habitats of helminths, which in the current climate change can complicate the epizootic situation of dangerous invasions. Changes in the phenology and ontogeny of pathogens of mass infestation under the influence of environmental factors, especially in geogelmint, need special control. Thus, for diktiokaul, prolongation of the seasonality of invasion by larvae was established, and the decrease in the extensiveness of individual trematodes shows a clear correlation with the dynamics of their intermediate hosts, which should be reflected in planned antiparasitic measures.

PGMG preparations can be used for deworming and disinfection of soil contaminated with excrement in places of animal accumulation, to prevent mass reinfection of animals.

The introduction into practice of modern science and best practices in the prevention of parasitic diseases by the free-keeping of wild ungulates will increase the number of their livestock, increase the production of quality, environmentally friendly, profitable products.

Prospects for further research. Further research will focus on the continuation of monitoring parasitological studies and factors contributing to the spread of helminthiasis and the improvement of deworming methods of wild ungulates in semi-detained conditions.

\section{References}

Danilkin, A. A. (2011). Fermerskoe ohotnich'e hozjajstvo: monografija. Moskva: "Tovarishhestvo nauchnyh izdanij KMK” (in Russian).
Davudov, D. M. (2008). Legochnye nematodozy ovec v uslovijah severo-vostochnogo Kavkaza (jekologija vozbuditelej, jepizootologija, profilaktika): avtoref. dis. ... d-ra biol. nauk: 03.00.19. Moskva (in Russian).

Dovhii, Yu. Iu., Shendryk, L. I., \& Feshchenko, D. V. (2011). Nematody dykykh kopytnykh Ukrainy. Visnyk Dnipropetrovskoho universytetu. Biolohiia. Medytsyna, 2(2), 28 32. http://nbuv.gov.ua/UJRN/vdubm_2011_2\%282\%29 7 (in Ukrainian).

Egorov, A. N. (1995). Fauna gel'mintov kopytnyh goskompleksa "Zavidovo" puti regulirovanij chislennosti naibolee patogennyh parazitov: avtoref. dis. ... kand. biol. nauk: 03.00.20. Moskva (in Russian).

Govorka, Ja., Maklakova, L. P., \& Mituh, Ja. (1988). Gel'minty dikih kopytnyh Vostochnoj Evropy. M.: Nauka (in Russian).

Kharchenko, V. O. (2004). Stan vyvchennia helmintofauny dykykh kopytnykh Ukrainy. Visnyk zoolohii, 18, 151-153. http://izan.nas.gov.ua/vit/PDF/Kharchenko\%202004a.pdf (in Ukrainian)

Pepko, V. O., Zhyhaliuk, S. V., \& Lysytsia, A. V. (2016). Znezarazhennia hruntu pidhodivelnykh maidanchykiv dlia dykykh kopytnykh tvaryn preparatamy PHMH. Aktualni problemy veterynarnoi biotekhnolohii ta infektsiinoi patolohii tvaryn: materialy shchorichnoi nauk.-prakt. konf. molodykh vchenykh, 16 chervnia 2016 r. Kyiv: IVM, 65-68 (in Ukrainian).

Ponomar, S. I., \& Kruchynenko, O. V. (2014). Monitorynh epizootolohichnoi sytuatsii helmintoziv shlunkovo-kyshkovoho traktu koriv na terytorii Ukrainy (za danymy veterynarnoi statystyky). Visnyk Poltavskoi derzhavnoi ahrarnoi akademii, 2, 116-118. Rezhym dostupu: http://nbuv.gov.ua/UJRN/ VPDAA 2014225 (in Ukrainian).

Sokolov, Yü. V., \& Mykytyn, Yu. V. (2014). Doslidzhennia terapevtychnoi efektyvnosti rozchynu fenbendazolu pry helmintozakh svynei. Veterynarna medytsyna Ukrainy, 9, 2426. Rezhym dostupu: http://nbuv.gov.ua/UJRN/ vetm_2014_9_7 (in Ukrainian).

Subbotin, A. M. (2011). Parazitarnye sistemy dikih kopytnyh i plotojadnyh i osnovy profilaktiki parazitozov na territorii Belarusii: avtoref. dis. ... d-ra biol. nauk: 03.02.11. Vitebsk (in Russian).

Vedennia myslyvskoho hospodarstva u 2014-16 rr. Statystychnyi biuleten [Elektronnyi resurs]. K.: Derzhavna sluzhba statystyky Ukrainy, 2014-16, 17. Rezhym dostupu: http://www.ukrstat.gov.ua/druk/publicat/Arhiv_u/07/Arch_misl bl.htm (in Ukrainian).

Veselyi, V. A. (2010). Pryrodna samorehuliatsiia poshyrennia zbudnykiv helmintoziv u navkolyshnomu seredovyshchi. Veterynarna medytsyna, 94, 270-271. Rezhym dostupu: http://nbuv.gov.ua/UJRN/vetmed_2010_94_111 (in Ukrainian).

Zdun, V. I. (1957). Obsledovanie molljuskov na zarazhennost' lichinkami digeneticheskih trematod. Cbornik: Metody izuchenija parazitologicheskoj situacii i bor'ba s parazitozami sel'skohozjajstvennyh zhivotnyh. K.: Iz-vo AN USSR (in Russian).

Zhyhaliuk, S. V., Makar, P. E., Dmytriiev, I. M., \& Zhyhaliuk, S. V. (2009). Dynamika masovykh trematodoziv u Rivnenskii oblasti. Naukovo-tekhnichnyi biuleten Derzhavnoho naukovodoslidnoho kontrolnoho instytutu veterynarnykh preparativ ta kormovykh dobavok i Instytutu biolohii tvaryn, 10(4), 474-479 (in Ukrainian). 